REFLECTIONS:

NEUROLOGY AND THE

HUMANITIES

Section Editor

Michael H. Brooke, MD

\title{
Reflections for October
}

Steven P. Ringel, MD

Address correspondence and reprint requests to Dr. Steven P. Ringel, University of Colorado Denver, 12631 E. 17th Avenue, B-185, Aurora, CO 80045 steven.ringel@ucdenver.edu

\section{BOOK ENDS}

It took a few seconds to realize that the phone was ringing and I wasn't dreaming. "Doc, this is Julie. I'm sorry to waken you but thought you would want to know. Kyle just died.”

Kyle's death was not unexpected-he had advanced muscular dystrophy with respiratory muscle failure. As I searched for words to comfort Julie, I was astonished by my own profound sadness. Physicians are cautioned to maintain professional distance from patients and their families, but my long history with Kyle and Julie caused me to break the rules.

I realized I'd known Kyle most of my professional life. Our connection punctuated many significant chapters in my career as I helped him navigate one obstacle after another. Although he struggled to breathe, he refused a ventilator. Despite growing weaker, he viewed each loss of a function as a hurdle to overcome- "It's no different than repairing an old car, Doc; just keep me running." I thought of many parallels in the way we approached life. While mine don't compare with his, we both faced inevitable disappointments, losses, and the need to adapt to new circumstances as optimists - people who saw life as a glass of water "half full" — not "half empty."

My mind drifted back 35 years when I first met Kyle. Like many other economically disadvantaged recruits who lacked formal education and vocational skills, Kyle was attracted to the glamorous portrayals of a military career. A high school dropout, at age 17 he had married Julie, who was pregnant with Rachel. Unemployed and with limited skills, the local Army recruiter's training opportunities and monetary incentives were tempting. He loved to repair cars and wanted to be in the Army's transportation pool. To save money, Julie and Rachel moved in with her parents in Greeley, Colorado. Kyle headed off to basic training at Fort Ord, California.

I also moved to Fort Ord but was able to bring my family with me for a new chapter in my life. Growing up in the Midwest, the transition to an Army neurologist in a military hospital that provided medical care for thousands of soldiers and military retirees constituted cultural shock. Located on the Monterey Bay peninsula, Fort Ord's cloud-covered, sandy topography was ideal for basic and advanced infantry training. After rigorous conditioning, recruits were assigned a more permanent location. The Vietnam War was winding down, the draft was ending, and recruitment efforts were in full swing for the new "All Volunteer" Army. Kyle was one of many unemployed young men who had enlisted and was learning to adjust to the rigors of boot camp. My sense of equilibrium was challenged by learning to salute, wear a uniform, help my family including a newborn adjust to a California lifestyle, and meeting Army expectations far away from a protected, middle-American educational environment.

Early into basic training a drill sergeant sent Kyle for evaluation. Despite his determination, Kyle couldn't meet required physical demands. I saw my job as treating Army personnel and their families' neurologic problems. An added responsibility was to identify recruits who had an "EPTS" medical condition- "existed prior to service"-since the Army wanted them discharged to avoid the medical liability of preexisting conditions. I was already interested in neuromuscular disorders and was proud to diagnose Kyle's weakness as limb-girdle muscular dystrophy. Although too new as a physician to appreciate the long-term issues that Kyle would face, I understood there was no treatment to reverse his muscle deterioration. Kyle was going to become progressively weaker.

We talked candidly about his future. I worried that being an automotive mechanic might be difficult. He showed me a picture of Julie and Rachel and assured me that he'd find a way to take care of them. "I'll find a job I can do, Doc." I arranged Kyle's Army discharge, and he went home to Colorado. I didn't imagine that I would ever see him again.

Beyond the boundaries of the Army post, living through the early 1970s was chaotic and unsettling. The Watergate break-in culminated in President Nixon's resignation. The sense of community at the Olympics in Munich was shattered when Israeli athletes were killed. The ensuing Yom Kippur War caused Arab countries to cut off oil shipments to countries supporting Israel. The subsequent gas crunch led to high oil prices, spiraling inflation, a tumbling stock market, and, most worrisome, significant job losses. Anxiety about the nation's future ran 
rampant and trust in government was low. Sound familiar? No one anticipated then that our country would experience similar political and economic upheaval years later.

Unexpectedly, I was reunited with Kyle. I had moved to Denver to direct the University's Muscular Dystrophy Clinic, where Kyle was receiving care. $\mathrm{He}$ was taking community college automotive classes and worked at Sears selling automotive parts. "Doc, take a look at this picture of Julie and Rachel. They're standing next to my custom car. I did all the restoration myself. Someday I'll own a custom shop," he told me excitedly.

Over the next 30 years, I watched Kyle progressively lose strength, mobility, and independence. Despite those limitations, he continued to work and welcomed a second daughter, Annie, to his family. All 3 of these women eventually did everything possible for Kyle. During those same years, my focus expanded from finding cures in the laboratory to include better ways to overcome my patients' day-today limitations.

Some of the high and low points of Kyle's odyssey paralleled my own experiences. While certainly less intense, I was challenged by career demands and disappointments, family illnesses and deaths, and the constant stress of juggling time between work and family. Just as everyone comes to grips with the trials life brings, so Kyle and I accommodated to ours.

Kyle progressed from a walker to a power chair. He rarely complained and somehow adjusted. Once he insisted that I come to the parking lot to watch him operate the lift that hoisted him into his van. "Doc, watch how I drive this beauty." Kyle maneuvered the chair and drove off using specially installed hand controls. Both he and I marveled at the technological advances that allowed him a modicum of independence.

I still remember Kyle struggling to master mobile arm supports to feed himself. When he was too weak to operate the hand control on his power chair, he used a head control. He rarely missed a day of work even when he could no longer drive himself. His family and coworkers anticipated his every need and were not the least bit reluctant to help him in the bathroom or with meals. At his funeral, a fellow employee told how inspired she was by Kyle's determination and that she looked forward to feeding him his lunch when he no longer could eat unassisted. His coworkers and family were an indispensable part of his life, and Kyle was equally important to them and to me.

Kyle's will to live slipped away as recurrent lung infections made it impossible for him to work. Julie and his daughters had a very difficult time accepting why Kyle refused a tracheotomy to make his breathing easier. "Doc, I've had a good life. I don't want to be tethered to a hose and unable to work. No car runs forever. We all have to die sometime."

During office visits, Julie or her daughters repeatedly asked me if a cure for muscular dystrophy was close at hand. I explained how potential research discoveries would ease suffering. We now understand disease mechanisms I never learned in medical school. I'm convinced we will discover effective treatments for many chronic disorders. As physicians unravel the complexity of human biology and dysfunction, we revel in the new questions before us but cringe when our academic answers provide no solace. A new genetic test confirmed that Kyle's particular form of muscular dystrophy is caused by a defect in the lamin A/C gene. Already preliminary attempts to insert a normal copy of the gene into people with this abnormality or to coax the body into making more effective proteins offer hope. But a "cure" is not imminent. Although this reductionist, step-by-step approach to research is essential, I struggle to convey to patients the value of the investment and even their personal commitment to help unravel the messages hidden in strands of DNA coiled up in chromosomes. It's a painstakingly complex process but one that offers promise. As a neuromuscular investigator, I am a tireless advocate for the technological advances that make our lives easier. But as a graying doctor who has cared for countless people with debilitating and fatal illnesses, I've learned valuable lessons that have nothing to do with scientific discoveries. When I first met Kyle at Fort Ord, no one had computers or cell phones, and we knew little about genetic defects. Yet, much of what was going on then is so similar to today's world. We are again waging unpopular wars, gas prices are chaotic, and our economy is glacially recovering from a downward spiral. Politically, our country is more divided than ever. We find it just as difficult as we did 35 years ago to see answers or a "light at the end of the tunnel." But patients and those challenges still require our commitment.

Kyle and the many others who continue to strugglepatients, families, the disadvantaged - have been my best teachers. Today's problems, whether a disease, an economic downturn, or a war, seem insurmountable compared to past challenges. Yet people like Kyle adjust to or overcome their difficulties just as our nation does.

Kyle's life was happy and full not because of the equipment he used and the therapeutic advances that prolonged his life. His determination and help from family and friends allowed him to manage his adversity. His example is instructive to all facing life's tests. 
His life was a series of challenges he overcame, and he died on his own terms.

I'm saddened that Kyle and his family are no longer part of my life. Certainly some of my idealism was shaped by political events in those formative years when I first met him. As my professional life has evolved, I've learned to adapt to many changes: new advances in science and technology, increasing bureaucratic requirements in medical practice, and funding shortages that preclude optimal treatment of the uninsured. But a constant in my evolution has been witnessing the power and determination of the human spirit.
The cycles of history remind me of the futility of trying to control the uncontrollable and the importance of adapting to change. Just as making a rare diagnosis is no longer the high point of my day, I no longer see the life of my patients with disabling illnesses as tragic. I never dreamed that my life would so intertwine with Kyle's, nor did I imagine that the tribulations of the 1970s would reappear following the peace and prosperity of the 1990s. I've learned a valuable lesson from my patients: we can overcome the most dramatic of challenges and remain optimistic about the future, particularly our expectations for medical discovery. 


\section{Neurology}

Reflections for October

Steven P. Ringel

Neurology 2010;75;1393-1395

DOI 10.1212/WNL.0b013e3181f73627

This information is current as of October 11, 2010

\section{Updated Information \& Services}

\section{Subspecialty Collections}

Permissions \& Licensing

Reprints including high resolution figures, can be found at: http://n.neurology.org/content/75/15/1393.full

This article, along with others on similar topics, appears in the following collection(s):

\section{Medical care}

http://n.neurology.org/cgi/collection/medical_care

Muscle disease

http://n.neurology.org/cgi/collection/muscle_disease

Palliative care

http://n.neurology.org/cgi/collection/palliative_care

Professional conduct and ethics

http://n.neurology.org/cgi/collection/professional_conduct_and_ethics Quality of life

http://n.neurology.org/cgi/collection/quality_of_life

Information about reproducing this article in parts (figures,tables) or in its entirety can be found online at:

http://www.neurology.org/about/about_the_journal\#permissions

Information about ordering reprints can be found online:

http://n.neurology.org/subscribers/advertise

Neurology ${ }^{\circledR}$ is the official journal of the American Academy of Neurology. Published continuously since 1951, it is now a weekly with 48 issues per year. Copyright Copyright $@ 2010$ by AAN Enterprises, Inc.. All rights reserved. Print ISSN: 0028-3878. Online ISSN: 1526-632X.

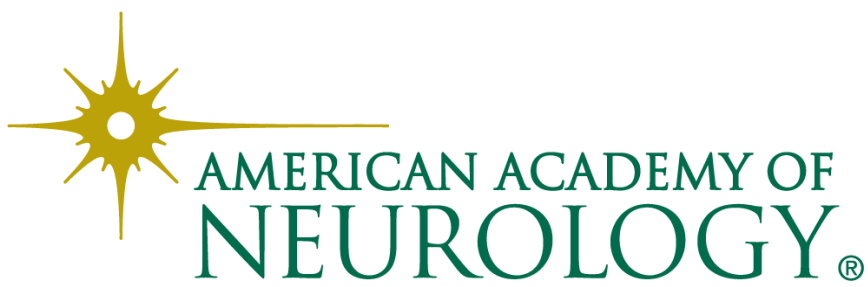

